UDC 658.1:338.439

KOMPANIIETS LIUDMYLA, Zaporizhzhia National University (Zaporizhzhia, Ukraine) E-mail: milalion@ukr.net, ORCID0000-0002-4137-2551

\title{
ORGANIZATIONAL CULTURE STUDY AS THE SYSTEM ELEMENT OF INTERNAL BUSINESS COMMUNICATION
}

The issue is devoted to the study of modern processes in the sphere of decision-making and organizational communicational systems building. The complex analysis of organizational culture as a component of social culture, system of values and beliefs, which determined personnel's behavior model and conditioned the general character of organization existence is performed. In particular, applying to comparative and critical analysis of various concept definitions of "organizational culture" and revealing the advantages of social and cultural approach as a platform for social structures analysis which formed value background for managerial decisions, the author considers organizational culture as a base for effective managerial decisions-making; defines the main classification principles of organizational culture; determines the structure on the ground of three-level conception: "surfaced", "beneath surface" and "deep" levels, which form "cultural paradigm" of an organization and coherent image. Furthermore, the typical internal components of organizational culture are highlighted and analyzed. Addressing the following objectives provides an opportunity, firstly, to organize social and philosophical concepts' analysis of organizational culture on global and local levels, whereas each relates to a special tool standard used within social and communication analysis; secondly, to define specific features' selection of organizational culture's influential factors on managerial decisions creation and their mechanisms of implementation. The crucial conclusions are: mutual connection determination between 1) the types of social structure and the peculiarities of organizational activity; 2) the classification features of organizational culture and intentions of managerial decisions; 3 ) levels of organizational culture and organizational values positioning; 4) a personal type and his ability to accept and transmit the fundamental achievements of organizational culture.

Key words: organizational culture; global and local dimensions; classification; cultural paradigm of an organization; organizational communications.

\section{Introduction}

Generating all social spheres of our country within civilized development demands an establishment of the new organization and communication constructs which are able to support and enhance social structure, which is opened and understandable for all world community. The social necessity of openness and clearness shapes the sequence of modern processes in the sphere of decision-making and organizational communicational systems building.

The aim and content of organizational communications have always considered a content of participants' social and cultural values, stereotypes, as well as they are determined by the participants' awareness of social responsibility to be the subjects of institutional development.

The study of mechanisms and the ways of organizational relationships, participants' ideas and stereotypes reflected on their professional decisions and acts is performed within social and cultural paradigm, the theoretical basis of which formed in the works of P. Bourdieu (Bourdieu, 1993 and 2005), D. Harris (1987), E. Hall (1989), G. Hofstede (2001), O. Temnitskiy (2007). They permit to determine social and cultural elements as the fundamental elements of managerial system, to define organizational culture which directs an action of the rest other factors (economic, social, political, national and ethnical). The following scientists explored how and why the organizational structure influenced on the managerial decisions'

ISSN 1728-9343 (Print)

ISSN 2411-3093 (Online) realization, among them were E. Schein (2002), T. Dyachenko (2009), F. Moghaddam (2008), M. Kozlovets (2011), T. Solomanidina (2003), O. Aleksandrova (2018) etc., and other scientists who came to the conclusion that the institutional structure in particular influenced on the managerial decisions' realization, namely its types (Solomanidina), internal components (Dyachenko), external attributes (Hofstede, Aleksandrova and etc.) and constituted the base of "cultural paradigm institution".

The aim of the issue is to provide a complex analysis of organizational culture as a component of social culture, system of values and beliefs, which determines personnel's behavior model and conditions the general character of organization existence. Reaching the aim is realized through the following research objectives:

- To analyze organizational culture as a reason for introduction of managerial effective decisions;

- To determine the main principles of organizational culture classification;

- To define a structure of organizational culture according to three-leveled conception: "surfaced", "beneath surface" and "deep" that shaped "cultural paradigm" of an organization and its integrated image;

- To highlight and analyze the mandatory internal components of organizational culture.

Addressing the following objectives provides an

SKHID No. 3 (161) May-June 2019 
opportunity to specify ideas about affecting factors of organizational communication directions, the possibility of quality changes and their realization mechanisms.

\section{Methods}

The researched methodological base is comparative and critical analysis of various concept definitions of "organizational culture" and social and cultural approach determination as a platform for social structures analysis which formed value background for managerial decisions. The author bases on an idea of three-level organizational culture: "surfaced" level is characterized by an internal influence of organizational culture; "beneath surface" level includes organizational values shared by members according to their reflection level in symbols and language and to the particular grade of their sensitive explanation of the "surfaced" level; "deep" level compounds fundamental organizational ideas accepted by the members for granted.

\section{Results}

The scientific novelty and specificity of the study are in social and philosophical consideration of organizational culture phenomenon with regard to further management instruments enhancement, which concerns:

1. To social and philosophical concepts' analysis of organizational culture on global and local levels;

2. To specific features' selection of organizational culture's influential factors on managerial decisions creation and their mechanisms of implementation.

\section{Discussions}

The factors of organizational culture which characterize society in general and influence on organizational activity and its interaction with external environment in global scale are traditionally characterized as global ones. The elements they are convincingly established by Ye. Shironina (2013) include: globalization; change of technical style; professional and religious culture and additionally time factor. Moreover the factors which characterize society in general as well as those ones which reveal a person and his ways of socialization can be classified as global factors. Consequently, they are: economic system of a country, political type of social structure, national culture, language and established norms, systems of family education, school education, informational background, the ways of professional socialization, etc. (Shironina, 2013).

If the global factors are to be considered in the light of social effectiveness of managerial decisions formation, in our view, the work of American scientist F. Moghaddam should be addressed to where two vectors of cultural essence characteristics are determined: the "democracy - dictatorship" and "market economy - planned economy" (Moghaddam, 2008: 74). This permits to determine four types of social structure that influence on peculiarities of international companies' activity: market democracy, market dictatorship, democracy with planned economy and dictatorship with planned economy. The USA can be related to the first type, China - to the second, the third type is presented by Sweden, the fourth - by Cuba. Due to the author the market democratic structure, in particular, facilitates the positive acceptance of cultural diversity.

One of the first classifications within comparative management was cultural division on high and low context cultures performed by $\mathrm{E}$. Hall (1989). The division is crucial from the perspective of communication organization in different cultures. Any event (or message) acceptance depends on a context; hence with the well-known information for a participant (recipient) that is not in the message, however it is connected with an event. The mentioned two types of cultures differ with the correlation of informational saturation of a message and a context.

The responsibility of communication success is put on a person who transmits information in low-context cultures. He should have a professional ability of accurate and detail description. American culture is a typical example of a low-context culture. The objects are traditionally called by their proper names, a situation is described maximally accurate and in detail. The special knowledge is not demanded from a recipient, about description process creation and development, about what are the crucial connections. The people are supposed to deal freely with each other and external restrictions have a general character.

The cultural assumption of such type of communication is a high level of individualism, freedom and people mobility. Managerial decisions are particularly approved by a manager himself with taking into account subordinates' ambitions, their abilities and possibilities from one side, and a wish for enrichment from the other. All managerial activity is based on a mechanism of individual responsibility, individual results evaluation.

Japanese culture is a typical high-context culture. The communications within a group are prevailed in Japanese society. The working places are not separated by any partitions and personnel is in close proximity with each other. The representatives of all hierarchical layers work under such conditions. Nevertheless, there are no physical or psychological barriers for communication.

Impersonal communications are an ordinary deal in Japanese office and encouraged by administration. Furthermore, communication, crucial issues discussions for a department or a whole organization take place outside the office, in an informal setting. It creates continuing informational flow that maintains a process of decision-making traditional for Japan which demands a consensus search. The fact that personnel is in the loop, reduces a necessity of the detailed message transmission which is a typical feature for low-context culture.

A message is not determined in high-context culture, as Japanese one; still it is accepted and interpreted as a part of common communication space existed between participants in the dialogue. Personnel behavior belonged to various culture types does not only differ in sphere of communication. E. Hall mentions that a director bears responsibility not in theory, but in practice for his employees' actions, who are below him on a career ladder in a high-context culture (Hall, E. \& Hall, M., 1989).

The authority's delegation is practiced in a low-context culture, the power is divided more equally, and a performer assumes personal responsibility. A man is evaluated due to his personal deeds and achievements.

In high-context cultures in managerial decision-making, the main aim of a manager is not a responsibility's centralization, but its division among all community members and creative feedback stimulation through fruitful moral and psychological atmosphere which secures maximal feedback from a working group.

Holland scientist G. Hofstede in his classical work about culture considers a few directions according to which a particular cultural type can be classified (Hofstede, 2001: 213): individualism / collectivism (describes power relations between a person and other persons in society, thus the measure of human behavior is defined due to predominance of individual or group members), powerful distance (determines a cultural attitude to hierarchical power relations, namely to unequal distribution of power), ambiguity avoiding (presents a cultural attitude to the fact of inability to envisage the future, hence whether the carriers of culture prefer the structured situations to the unstructured 
ones), masculinity - feminism (defines the social division of roles due to a gender marker), short-term / long-term orientation (encompasses that the long-term cultures concentrate on the future and maintain the modern values which are not necessary to produce the quick profit, whereas the cultures with short-term orientation are aimed at the past and the present, maintain respectful attitude to traditions and performance of social responsibilities).

On G. Hofstede's assumption a culture as a "collective spiritual program" defines the patterns of social behavior. The culture is substituted by labor; however the process is rather slow. It has a tendency to be embodied, crystallized in social institutes. The social institutes, by contrast, limit and stimulate various methods of thinking to some extent.

One attempt to develop cultural classification on the base of a complex system with various indicators influencing on business behavior, belongs to $R$. Lewis who has defined three cultural types.

Linear-active cultures. The representatives are oriented on tasks. They carefully plan their actions and do things one at a time. The Germans, Englishmen, Americans, Australians, New Zealanders, Scandinavians (except Finns) are in this group.

Multi-active cultures. The representatives are oriented on people. They are lively, loquacious, do many things at once, planning their priorities not according to a time schedule, but according to the relative thrill or importance that each appointment brings with it. The Spanish, Italians, Latin Americans and Arabs are members of this group.

Reactive cultures. The main feature of this type of culture is to attach significant importance to courtesy and ability to listen. The typical representatives are the Japanese, Chinese, Finns (Lewis, 2006).

$\mathrm{H}$. Triandis drew attention to the difference in the types of informational processes in various modern business cultures. Particularly, social characteristics of a source and information recipient play a fundamental role in information acceptance (Triandis, McCuster, Hui, 1990: 114). Considering abovementioned, the cultures are divided on those where a partner's competence in communication sphere is important and on the cultures where information acceptance depends on a personal status within a group. According to the last group the individual social features are crucial, namely background, gender, religion, etc.

The considered opinions give the reasons to draw some conclusions about typology of organizational culture, internal components and external attributes, the main principles and functions, structure and decision-making criteria, taking into account global factors.

For instance, social effectiveness of managerial decisions can be determined by:

a) a level of freedom in the communication paradigm building (democracy - dictatorship);

b) the circumstances of information transmission and acceptance (low-context cultures imply personal responsibility for information transmission and acceptance, whereas collective responsibility logically develops in highcontext cultures);

c) the spiritual bases of human behavior (which stimulate and determine different methods of thinking connected with:

- individual priority over collective one;

- attitude to structured connections in organization;

- gender determination;

- time orientation on results' achievement).

d) intentionality that characterizes the business behavior peculiarities of different cultures representatives:

- orientation on tasks performance within linear-active cultures;

ISSN 1728-9343 (Print)

ISSN 2411-3093 (Online)
- orientation on impersonal connections building in multi-active cultures;

- orientation on communication tradition preservation in reactive cultures.

e) participants' positioning of information and communication process:

- due to a competence;

- due to a status.

The local factors influenced on managerial decisions are to be considered. Concomitantly, we mention that the factors, acting on organizational level and forming formal and informal connections that define variety of organizational cultures in total, traditionally are related to local factors. Among them are the following: a) the factors connected with an organizational activity (technology; organizational size; personnel type; property relations; organizational structure); b) the factors connected with a management style (aims setting; communicational networks; conflict management; methods of motivation); c) the factors connected with the employees' special preferences and aspirations (interests; organizational commitment); d) the factors connected with the employees' differentiation and value for an organization (personnel categories, individual involvement in formal and informal structures).

An issue about the relevance to a particular category is closely connected with group affiliation, who can be supposed to be a group member (an insider) and whom not. Naturally, communication is accepted with much more trust within a group and communications are more intensive among its members than with the third persons. The peculiarities of a communication process are determined according to groups and their size.

For instance, community cohesion defines the effects of their self-organization and subcultures differentiation. Simultaneously, the "smooth" department divisions facilitate the common corporative culture creation. The same processes can be followed in strategic alliances. Furthermore, "smoothness" or "hardness" of the division ways can increase or decrease the easiness of a supplier change or another business partner (Aleksandrova, 2015).

The value orientations and personal beliefs that are presented in an organizational environment are directly connected with the dominant religion in a society. Such approach is demonstrated in Noboru Yoshimura's and Philip Anderson's typology in a straightforward way (Yoshimura and Anderson, 1997).

Eventually, they defined three main types of organizational culture according to a national feature - the Western-European, Northern American and Japanese types. All other cultures borrow and synthesize the particular features of three main types. Consequently, the provided typology covers only the cardinal cultural moments, however, even according to this, the fundamental differences among them are noted. The differences are displayed in a contradiction of the Western and Eastern organizations as well as within the organizations of Western-type.

For instance, European organizations are meticulous in formation of long-term programs and their activity strategies; in contrast American companies are interested in the events with a quick effect. European and American organizations belong to the Western civilization, the fact is reflected in the main values, namely in variety, mobility and individual freedom. The main values of Japanese organizations are stability, homogeneity, mutual trust and safety.

K. Cameron and R. Quinn have defined the following types of organizational culture: clan, adhocracy, hierarchy and market culture.

Clan culture is characterized by the internal orientation

SKHID No. 3 (161) May-June 2019 
on flexibility of problem solving. The positive features of clan culture are friendly, favorable social and psychological climate, community cohesion, administrative care of employees, devotion to traditions and duties' performance.

Adhocracy culture differs from clan culture according to the external orientation. Pioneering spirit, creativity in problem solving, an ability to take risks is inherent in this type of culture. Individual initiative and freedom are considered important.

Market culture as adhocracy culture is oriented on the external environment; however in this type of culture stability and control are valued. Such organizations are resultoriented and goal-focused. The personnel is required to be competitive, the leaders are tough and demanding.

Hierarchy culture compounds internal orientation with stability and control as the means of problem solving. Consequently processes' formalization, plan-based character, stability and reliability are fundamental for hierarchy culture (Cameron, Quinn, 2011: 68-79).

American scientist Ch. Handy has offered a model of organizational culture based on power division and determination of individual value orientations. The four types of organizational culture were proposed: 1) power culture, 2 ) task culture, 3) person culture, 4) role culture. Let us understand them in detail.

Power culture is based on power and tough control, on leader's individual features. The strict hierarchy in such companies is a rule. The cardinal positive characteristics of companies with such type of culture are their mobility and high adaptation ability.

Role culture is characterized by existence of bureaucratic procedures; clear regulation of employees' rights and duties; available programs of gradual career development. Such type of culture is established in the companies which provide activity on the stable markets. The positive features of role culture are transparency and predictability, among negative is the low level of adaptation ability.

Person culture is created in the companies who are the unities of high-level specialists in some sphere. Power and control in such organizations are coordinative in nature. Person culture has a short-term character and is tended to be reshaped into another type of organizational culture. Presented type of culture creates the optimal conditions for individual development; still the employees' responsibility degree is rather high.

Task culture is defined by clear orientation on particular tasks accomplishment that is crucial under market conditions which dynamically develops. Team working methods and tough control as well as reporting methods are used for general enhancement of working effectiveness at the enterprises with such cultural type. Taskoriented culture provides a positive result for the enterprises which are working under conditions of tough competition and is not acceptable for organizations in crisis.

The main conclusion of $\mathrm{Ch}$. Handy is that corporate culture is not static; it is constantly changing with the enterprise modifications. In other words, Handy's model is an illustration of organizational culture's change according to the developmental stage of an enterprise. The stage of the emergence and establishment corresponds with power culture, the stage of development covers by role culture, the stage of flourishing is presented by person culture, and the stage of decline and revival are connected with task culture (Handy, 2008: 253-256).

From the sense of organizational culture characterization through the main types of classification, we are moving to the analysis of cultural structure. Three level structure of organizational culture was offered by E. Schein (Schein, 2002: 30)
The surface level is presented by visual cultural artefacts or formal hierarchical structure of organization, namely system of leadership, technologies, the stable ways of interactions, community members' behavior. It is an external manifestation of organizational culture, everything that a man can see or feel, in particular corporative symbolic, logos, corporate calendars, flags, hymn. Emotional atmosphere, myths, legends and stories connected with organizational establishment, leaders' activity and the deeds of prominent workers are related to a "symbolic" level. The events and phenomena are easy to be determined; however they are sophisticated in interpretation within the terms of organizational culture without any knowledge about other levels. The fact pre-empts a beneath artefacts' level called "espoused values" which includes the group-shared values according to the degree of its reflection in symbols and language, particularly how they assume sensible explanation of the higher level.

Intentionally recorded in organizational documents, they are aimed to be cardinal in common activity of its members (for instance "a client is always right") in the form of organizational strategy, goal, philosophy. Here moral views, ethical rules, code of behavior can be found. There are particularly the values recognized by the members of an organization or those which are encouraged by a leader. Schein is convinced that the last one has the main role in "organizational ideology" creation and enhancement.

Nevertheless, a culture is not determined via declared values, still it subordinates to unconscious "basic ideas" that are in the fundament of the third level of organizational structure. A level of "Basic underlying assumptions" covers fundamental organizational ideas taken for granted (among them essence of things and phenomena, attitude to common human values, beliefs and convictions, time and space acceptance, truth nature and the ways of its reception, the right relations between a person and a group), namely all that is difficult to understand even by the members of an organization without special consideration on the issue. The unity of the basic ideas creates so-called "cultural paradigm" of an organization and forms its coherent image.

According to E. Schein, the process of acceptance and structuring some ideas in human consciousness is conditioned by an individual aspiration of avoiding ambiguity, reaching determinacy in ordinary life. "Cultural paradigm" facilitates to avoid the ambiguity and establishes the individual attitude to the external world, its ideas about nature, human, essence of his activity through global significance (within the organization).

It is fair to mention that E. Schein considers "surface" level as objective culture with the following components: economic organizational culture as a result of economic thought (culture of labor organization, culture of labor conditions, culture of labor means, etc.), culture of distribution, culture of consumption, culture of exchange. On the other hand, "beneath" and "deep" levels are defined as subjective culture conditioned by a thinking mechanism of employees (employers and employees culture; ethical and esthetic culture; culture of behavior (motivation); communication culture; conflicts solution culture). Simultaneously, each cultural element can be divided on others of smallscale, for instance on law, political culture, etc.

As we have mentioned above, the religious, value, national and other factors influence on establishment of business impersonal communication on horizontal level. The crucial factors that have impact on such communication are the following:

a) National factor (influences on the duration of business communication within a project and relevant back- 
ground creation of individual and collective achievements of an employee).

b) Factor of direction. If cultural peculiarities of employees orient them on task achievement being undertaken by an organization, a constructive environment for goals realization will be created within an organization. Consequently, it will be coherence or mutual assistance, or clear functional division, or leader's tough operational control. If the personnel (employees) are oriented on external environment via objectives' implementation, competition will arise between them; moreover the nontraditional innovative approaches, creative motivators and selfrealization will strengthen via tasks performance.

c) Factor of organizational life-cycle is presented in the specification of internal and external cultural directions according to which horizontal organizational communications are dependent, whereas particular type of horizontal connections is predominant on different stages of a cycle.

d) Factor of "symbolism" covers the visual cultural artefacts which facilitate corporative spirit to occur and influence on consciousness, behavior and communication of all members of corporate relations as well as the individuals who are outside, however are related to them.

\section{Conclusions}

Having studied the essential characteristics of organizational culture in the global and local dimensions and the possibility of quality changes, embodied in theoretical models and various scientific structures of organizational culture, according to social and cultural approach, we have determined the following conclusions:

1. The essence of organizational culture as a factor of managerial decisions' effectiveness enhancement is revealed through the typology, internal components and external attributes, the main principles and functions, as well as through structure and decision-making criteria. Two directions ("democracy - dictatorship" and "market economy - planned economy") in characteristic of cultural essence permit to define four types of social structure which influence on the peculiarities of organizational activity, among them: market democracy, market dictatorship, democracy with planned economy and dictatorship with planned economy.

2. The managerial decisions are based on the following grounds of classification of organizational culture: individualism / collectivism; masculinity / feminism; short-term / long-term distance; power distance; ambiguity avoidance. The division of organizational cultures on linear-active, multi-active and reactive provides general awareness in managerial decisions making. Due to the first cultural type the community representatives are oriented on a task, due to the second - on people, due to the third - on a process. According to the national marker, organizational cultures are divided on the Western European, Northern American and Japanese. Owing to the problem-solving feature, clan, adhocracy, hierarchy and market, cultures are highlighted. Moreover, according to the division of power responsibilities and value orientations, power, task, person and role organizational, cultures are defined.

3 . The structure of organizational culture is consisted of three levels: "surface" level characterized by the external exhibition of organizational culture; "beneath the surface" level includes the group-shared values according to a degree of its reflection in symbols and language, particularly how they assume sensible explanation of the higher level; "deep" level contains fundamental organizational ideas accepted by the members for granted. The unity of the basic ideas creates so-called "cultural paradigm" of an organization and forms its coherent image. Conse- quently, it can be stated that a paradigm of organizational culture should be taken into account in managerial decision-making.

4. Behavior stereotypes, rituals and traditions, group norms, declared values, philosophy of an organization, the rules of behavior, restrictions, organizational climate, practical experience, integrational symbols belong to mandatory internal components of organizational culture. Among external attributes that identify a type of cultural organization on micro and macro levels are personal consideration in an organization; communication system and language; general outlook and self-representation; human interconnections; values and norms, and their way of preservation; beliefs and loyalty; employee's developmental process and education.

\section{REFERENCES}

Aleksandrova, O. S. (2015). Korporatyvna kultura yak chynnyk stanovlennya i rozvytku suchasnoho universytetu. Neperervna profesiyna osvita: teoriya i praktyka. (3), 21-26 (In Ukrainian).

Aleksandrova, O., Batchenko, L., Dielini, M., Lavryk, U. (2018). Specifics of Managing Competitiveness of Present-day University on Principles of Social Responsibility. Naukovyi Visnyk Natsionalnoho Hirnychoho Universytetu (Scientific Bulletin of National Mining University), (4), 157-165. (In English) DOI: https:/ /doi.org/10.29202/nvngu/2018-4/21

Bourdieu, P. (1993). Sotsialnoye prostranstvo i genezis klassov. Sotsiologiya politiki: (translat., ed. by N. A. Shmatko). Moscow: Socio-logos, 329 p. (In Russian)

Bourdieu, P. (2005). Sotsialnoye prostranstvo: polya i praktiki Moscow: Tsentr gumanitarnykh tekhnologiy. Retrieved from http:/ /gtmarket.ru/laboratory/basis/3707/3708 (In Russian)

Harris, D. L. and Moran, R. T. (1987). Managing cultural differences [2nd ed.]. Houston, TX: Gulf Publishing Company, 431 p. (In English)

Hall, E T. and Hall, M. R. (1989). Understanding Cultural Differences. Yarmouth, ME: Intercultural Press, 320 p. (In English)

Hofstede, G. (2001). Culture's Consequences: Comparing Values, Behaviors, Institutions, and Organizations Across Nations (2 ed.). Ed. Thousand Oaks, CA: Sage, 358 p. (In English)

Temnitskiy, A. L. (2007). Issledovatelskiye vozmozhnosti kategorii "sotsiokulturnost"'. Sotsiologiya: metodologiya, metody $i$ matematicheskoye modelirovaniye. (24), 73-84. (In Russian)

Schein, E. (2002). Organizatsionnaya kultura i liderstvo: Postroyeniye, evolyutsiya, sovershenstvovaniye (translat. from English). St.Petersburg: Piter, 336 p. (In Russian)

Dyachenko, T. O. (2009). Zahalni pidkhody pry vprovadzhenni zmin orhanizatsiynoyi kultury. Formuvannya rynkovykh vidnosyn v Ukrayini. 8 (99), 116-119. (In Ukrainian)

Moghaddam, F. M. (2008). Multiculturalism and intergroup relations: psychological implications for democracy in global context. American Psychological Association. Washington, DC, 207 p. (In English)

Kozlovets, M. A. (2011). Natsionalna identychnist yak sotsiokulturnyy fenomen. Visnyk Zhytomyrskoho derzhavnoho universytetu imeni Ivana Franka. (60), 3-11. (In Ukrainian)

Solomanidina, T. O. (2003). Organizatsionnaya kultura kompanii. Moscow: Upravleniye personalom, 455 p. (In Russian)

Shironina, Ye. M. (2013). Teoretiko-metodicheskiy podkhod k klassifikatsii faktorov formirovaniya i razvitiya organizatsionnoy kultury. Ekonomika i predprinimatelstvo. № 12-2(41). Pp. 891896. Retrieved from https://elibrary.ru/item.asp?id=20932132 (In English)

Lewis, R. D. (2006). When Cultures Collide: Leading Across Cultures. Boston-London: Nicholas Brealey International, Retrieved from http://www.utntyh.com/wp-content/uploads/2011/11/WhenCultures-Collide.pdf (In English)

Triandis, H. \& McCuster, C. \& Hui, C. (1990). Multimethod Probes of Individualism and Collectivism. Journal of Personality and Social Psychology. Vol. 59. № 5, 106-120. (In English)

SKHID No. 3 (161) May-June 2019 
Yoshimura, N. and Anderson, P. (1997). Inside the Keisha: Demystifying Japanese Business Behavior. Harvard Business School Press, 259 p. (In English)

Cameron, K. S. \& Quinn, R. E. (2011). Diagnosing and Changing Organizational Culture: Based on the Competing Values Framework (3rd ed.). San Francisco: Jossey-Bass. (In English)

Handy, Ch. (2008). Budushcheye krupnykh korporatsiy i melkogo biznesa. Moscow: Alpina Biznes Buks, 356 s. (In Russian)

\section{LIST OF REFERENCE LINKS}

Александрова О. С. Корпоративна культура як чинник становлення і розвитку сучасного університету. Неперервна профресійна освіта: теорія і практика. Науково-методичний журнал. 2015. Випуск 3. С. 21-26.

Aleksandrova O., Batchenko L., Dielini M., Lavryk U. Specifics of Managing Competitiveness of Present-day University on Principles of Social Responsibility. Науковий вісник національного гірничого університету. 2018. No 4. С. 157-165.

Бурдье П. Социальное пространство и генезис классов. Социология политики: (пер. с фр. Н. А. Шматко) / [сост., общ. ред. и предисл. Н. А. Шматко]. Москва: Socio-logos, 1993. 329 с.

Бурдье П. Социальное пространство: поля и практики: сборник статей / [сост., общ. ред. пер. и послесл. Н. А. Шматко]. Москва: Центр гуманитарных технологий. URL: http://gtmarket.ru/laboratory/basis/3707/3708 (дата звернення: 12.03.2019)

Harris D. L., Moran R. T. Managing cultural differences [2nd ed.]. Houston, TX: Gulf Publishing Company, 1987. 431 p.

Hall E T., Hall M. R. Understanding Cultural Differences. Yarmouth, ME: Intercultural Press, 1989. 320 p.

Hofstede G. Culture's Consequences: Comparing Values, Behaviors, Institutions, and Organizations Across Nations [2 ed.]. CA: Sage, 2001. 358 p.

Темницкий А. Л. Исследовательские возможности категории "социо-культурность". Социология: методология, методы и математическое моделирование. 2007. № 24 . C. 73-84.
Шейн Э. Организационная культура и лидерство: Построение, эволюция, совершенствование: (пер. с англ. С. Жильцова, А. Чеха; под ред. В. А. Спивака. Санкт-Петербург: Питер, 2002. 336 c.

Дяченко Т. О. Загальні підходи при впровадженні змін організаційної культури. Формування ринкових відносин в Україні. 2009. № 8 (99). С. 116-119.

Moghaddam F. M. Multiculturalism and intergroup relations: psychological implications for democracy in global context. American Psychological Association. Washington, DC, 2008. 207 p.

Козловець М. А. Національна ідентичність як соціокультурний феномен. Вісник Житомирського державного університету імені Івана Франка. 2011. № 60. С. 3-11.

Соломанидина Т. О. Организационная культура компании. Москва: Управление персоналом, 2003. 455 с.

Широнина Е.М. Теоретико-методический подход к классификации факторов формирования и развития организационной культуры. Экономика и предпринимательство. 2013. № 12-2(41). C. 891-896. URL: https://elibrary.ru/item.asp?id=20932132 (дата звернення 13.08.2018).

Lewis R. D. When Cultures Collide: Leading Across Cultures. Boston-London: Nicholas Brealey International, 2006. URL: http:// www.utntyh.com/wp-content/uploads/2011/11/When-CulturesCollide.pdf (дата звернення 22.11.2018).

Triandis H., McCuster C., Hui C. Multimethod Probes of Individualism and Collectivism. Journal of Personality and Social Psychology. 1990. Vol. 59. № 5. P. 106-120.

Yoshimura N. and Anderson P. Inside the Keisha: Demystifying Japanese Business Behavior. Harvard Business School Press, 1997. 259 p. (In English)

Cameron K. S. \& Quinn R. E. Diagnosing and Changing Organizational Culture: Based on the Competing Values Framework (3rd ed.). San Francisco: Jossey-Bass, 2011. (In English)

Хэнди Ч. Будущее крупных корпораций и мелкого бизнеса. Москва: Альпина Бизнес Букс, 2008. 356 с.

Компанісць Людмила,

Запорізький начіональний університет (м. Запоріжжя, Украйна)

e-mail:milalion@ukr.net, ORCID 0000-0002-4137-2551

\section{ДОСЛІДЖЕННЯ ОРГАНІЗАЦІЙНОЇ КУЛЬТУРИ ЯК ЕЛЕМЕНТА СИСТЕМИ ВНУТРІШНЬОФІРМОВИХ КОМУНІКАЦІЙ}

Стаття присвячена дослідженню сучасних процесів у сфері прийняття рішень і побудови комунікаційних систем організації. Виконано комплексний аналіз організаційної культури, як складової культури суспільства, системи цінностей та переконань, які визначають моделі поведінки працівників і обумовлюють характер життєдіяльності організації. Зокрема, використовуючи порівняльно-критичний аналіз різних концептуалізацій феномену "організаційна культура" та показуючи переваги соціокультурного підходу як платформи для аналізу соціальних структур, що формують ціннісне підґрунтя менеджерських рішень, авторка розглядає організаційну культуру як чинник формування ефективних менеджерських рішень; встановлює основні принципи класифікації організаційної культури; визначає її структуру на основі концепції трьох рівнів: "поверхневий", "підповерхневий" та "глибинний", які формують "культурну парадигму" організації іії цілісний образ; виділяє та аналізує типові внутрішні складові органі-за-ційної культури. Вирішення цих задач дозволило, по-перше, систематизувати соціально-фрілософські концепції, які осмислюють феномен організаційної культури, за глобальним та локальним рівнями, кожен з яких відповідає певному рівню інструментарію, що застосовується в соціально-комунікативному аналізі; по-друге, визначити, яким чином і якою мірою організаційна культура впливає на прийняття рішень топ-менеджерами компаній. Важливими висновками роботи також є визначення взаємозв'язку: 1) між типами суспільного устрою та особливостями діяльності організацій; 2) між класифікаційними ознаками організаційної культури та інтенціями менеджерських рішень; 3) між рівнями організаційної культури і позиціонуванням організаційних цінностей; 4) між типом особистості і її готовністю до сприйняття та подальшої трансляції основних здобутків організаційної культури.

Ключові слова: організаційна культура; глобальний і локальний вимір; класифрікація; культурна парадигма організації; організаційні комунікації.

(C) Kompaniiets Liudmyla

Надійшла до редакції: 05.04.2019

Прийнята до друку: 31.05.2019

СХІД № 3 (161) травень-червень 2019 р. 